\title{
Oassédio moral nas relações de trabalho do(a) assistente social: uma questão emergente
}

\section{Bullying in the social worker's labor relationships - an emerging issue}

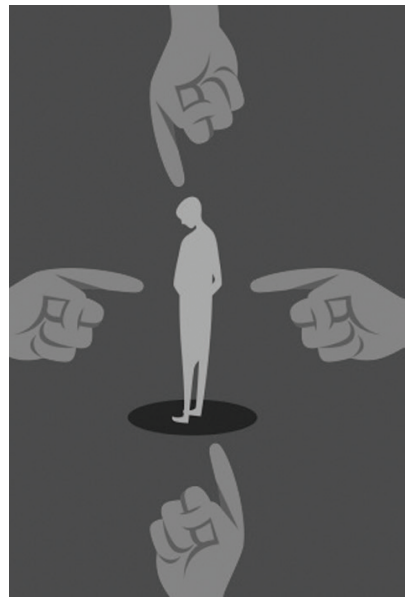

\author{
Ociana Donato da Silva* \\ Assistente social na Universidade de Taubaté, SP, Brasil.
}

\author{
Raquel Raichelis** \\ Professora do Programa de Estudos Pós-Graduados em Serviço Social da \\ Pontifícia Universidade de São Paulo (PUC-SP), Brasil.
}

\begin{abstract}
Resumo: O presente artigo é resultado da dissertação de mestrado que teve como objetivo analisar a prática do assédio moral como uma nova estratégia de gestão das relações de trabalho no atual contexto da reestruturação produtiva, com enfoque nos(as) trabalhadores(as) assistentes sociais. A pesquisa realizada evidenciou as situações vexatórias e humilhantes a que são submetidos os(as) profissionais, que se repetem e se prolongam durante a jornada de trabalho, provocando danos morais, sofrimento, desgaste mental e adoecimento.
\end{abstract}

Palavras-chave: Trabalho do(a) assistente social. Assédio moral. Ideologia gerencialista. Adoecimento. Direitos violados.

\begin{abstract}
The present article resulted from a master's degree dissertation whose aim was to analyze bullying as a new strategy of management in labor relationships in the current context of production restructuring, with an emphasis on social workers. The research undertaken showed the annoying and humiliating situations the professionals are subject to. Such situations are repetitive, they go on during the working hours, and they cause moral damage, suffering, mental strain and illness.
\end{abstract}

Keywords: Social worker's work. Bullying. Managerial ideology. Illness. Violated rights.

\footnotetext{
*E-mail: ocianadonato@gmail.com.

**E-mail: raichelis@uol.com.br.
} 


\section{Introdução}

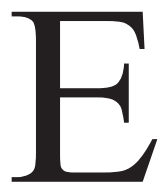

ste artigo $^{1}$ tem o objetivo de analisar o assédio moral nas relações de trabalho do(a) assistente social, como expressão das novas estratégias de organização e gestão do trabalho que se desencadearam a partir dos anos de 1990 em resposta do capital a mais uma de suas crises.

Sabe-se que o sofrimento e a opressão são fenômenos antigos no mundo do trabalho, porém a categoria assédio moral passou a ser utilizada mais recentemente. Problematizar esta questão torna-se relevante, pois o assédio moral provoca adoecimento físico e mental dos(as) trabalhadores(as) por acirrar a superexploração promovida pelo capital e incrementada pelo neoliberalismo, que fragilizou os direitos conquistados pela classe trabalhadora com os processos de sucateamento dos sistemas de proteção social, terceirização da força de trabalho, responsabilização dos indivíduos pelas suas carências, desresponsabilização do Estado perante os direitos de cidadania, privatização das estatais rentáveis, entre outros.

A flexibilização das relações de trabalho, uma das expressões da precarização, produziu novas formas de gerenciamento dos recursos humanos, sendo o assédio moral uma delas. Por outro lado, o enfraquecimento das lutas sindicais abriu as portas para o aprofundamento da opressão no trabalho.

A partir deste contexto, a prática do assédio moral é compreendida como violação dos direitos humanos e como estratégia de dominação do capital nas relações de trabalho que, na atualidade, estão cada vez mais precarizadas (Druck, 2009) e intensificadas (Dal Rosso, 2008) através de mecanismos de violência (Barreto, 2005 e 2006) que submetem a classe-que-vive-do-trabalho (Antunes, 2009) aos propósitos da reestruturação do trabalho na sociedade contemporânea, violando direitos trabalhistas e afetando as condições de vida e de trabalho.

Considerar o(a) assistente social como parte integrante da classe-que-vive-do-trabalho (Antunes, 2009) sinaliza que ele(a) não está isento(a) das mudanças estruturais ocorridas no mundo do trabalho. Neste sentido, pretende-se demonstrar como o assédio moral tem se manifestado nas experiências vivenciadas por assistentes sociais nos vários espaços sócio-ocupacionais em que se inserem, produzindo efeitos deletérios em sua saúde física e mental.

1. Elaborado com base na dissertação de mestrado de Ociana Donato da Silva, defendida no PEPG em Serviço Social da PUC-SP em 2014, sob orientação da profa. dra. Raquel Raichelis. 


\section{Reestruturação produtiva, reforma gerencial do Estado e políticas sociais}

No contexto mundial, a partir de 1970, desencadeia-se a reestruturação do sistema produtivo em resposta à crise estrutural das formas de acumulação que vigoraram desde a Segunda Guerra Mundial. A organização taylorista-fordista tornou-se hegemônica durante todo o século XX, espraiando-se para todas as organizações sociais que buscavam padronização, controle e eficiência do trabalho, transformando-se em ideologia dominante das relações sociais.

O taylorismo propunha a aplicação de princípios científicos na organização do trabalho, a separação entre as atividades de concepção e gestão, maior racionalização do processo produtivo por meio do estudo e controle dos ritmos, movimentos e da velocidade do trabalho.

Com o fordismo foi possível aumentar exponencialmente a produtividade do trabalho através da introdução de novas estratégias de gestão, entre as quais: uso mais adequado, na ótica do capital, das horas trabalhadas; aumento do controle das atividades dos(as) trabalhadores(as), em que o cronômetro é o símbolo emblemático; maior divisão e parcelamento das tarefas; mecanização de parte das atividades com a introdução da linha de montagem e do uso da esteira rolante na cadeia produtiva; e um sistema de recompensas e punições conforme o comportamento do operariado no interior da fábrica.

Para Antunes (2009, p. 38),

De maneira sintética, podemos indicar que o binômio taylorismo/fordismo, expressão dominante do sistema produtivo e de seu respectivo processo de trabalho, que vigorou na grande indústria, ao longo praticamente de todo o século XX, sobretudo a partir da segunda década, baseava-se na produção em massa de mercadorias, que se estruturava a partir de uma produção mais homogeneizada e enormemente verticalizada. (Grifos do autor)

No século XXI, diante da crise estrutural do capital, emergiu a era da acumulação flexível e do chamado toyotismo, com vistas a superar os limites do regime fordista de acumulação, bem como sua rigidez face aos novos requisitos de competitividade e de acirramento da concorrência mundial intercapitalista. Essa nova estratégia de acumulação capitalista desencadeia novas formas de organização e gestão do trabalho, nas quais a flexibilização, em diferentes níveis, é a mola-mestra para a redução dos custos da força de trabalho e reversão da queda nas taxas de 
lucro do capital. Com a acumulação flexível, o mercado de trabalho sofre profundas e regressivas metamorfoses, com impactos nos contratos de trabalho (temporários, em tempo parcial, terceirizados, entre outros), na maior rotatividade de trabalhadores, precarização do emprego e intensificação do trabalho.

Para alguns autores, como Souza (2011), é nesse contexto que pode ser situada a origem do assédio moral, quando são internalizadas nas relações de trabalho o controle e o uso manipulatório das emoções e dos afetos dos trabalhadores, processo que nos remete à alienação e aos objetivos do capital de internalizar cada vez mais profundamente a reificação capitalista na subjetividade da "classe-que-vive-do-trabalho". Antunes (2010), em sua análise sobre a nova morfologia do trabalho, chama a atenção para esse processo, advertindo que o ideal de todo capitalista é fazer com que cada trabalhador(a) possa tornar-se um(a) "déspota de si próprio(a)". A partir daí seria possível, como estamos verificando atualmente no sistema de produção flexível, a eliminação de vários cargos para tarefas de controle das metas de produtividade, delegando-se esse controle aos(às) próprios(as) trabalhadores(as), individualmente ou por meio dos círculos de qualidade.

No caso do Brasil, nos anos de 1990, foi possível assistir a inúmeras mudanças ocasionadas pelo projeto neoliberal, que teve início no governo Collor e se consolidou na gestão de Fernando Henrique Cardoso (FHC), as quais consistiram na privatização, flexibilização e terceirização da força de trabalho, que resultaram no projeto de contrarreforma do Estado (Behring e Boschetti, 2011), ou seja, sob o mote das "reformas" ocorre um enxugamento do Estado, com evidente desprezo das conquistas sociais garantidas na Constituição de 1988.

O Plano Diretor da Reforma do Aparelho do Estado (1995) do governo FHC, elaborado por Bresser-Pereira, então ministro da Administração e da Reforma do Estado (Mare), definiu as bases da contrarreforma do Estado:

É preciso, agora, dar um salto adiante, no sentido de uma administração pública que chamaria de "gerencial", baseada em conceitos atuais de administração e eficiência, voltada para o controle dos resultados e descentralizada para poder chegar ao cidadão, que, numa sociedade democrática, é quem dá legitimidade às instituições e que, portanto, se torna "cliente privilegiado" dos serviços prestados pelo Estado. (Brasil, 1995, p. 7)

O reordenamento da "política de gestão dos recursos humanos" na esfera estatal atingiu os direitos conquistados pelo funcionalismo público em vários 
aspectos: terceirização da força de trabalho; adoção da avaliação quantitativa de desempenho, estimulando a competição entre trabalhadores; ampliação de dois para três anos do tempo do estágio probatório; reforma conservadora na previdência pública com ampliação da idade mínima e aumento do tempo de contribuição para aposentadoria, entre outros.

Destaca-se que a reforma gerencial do Estado disseminou a ideologia gerencialista nas relações de trabalho e nas formas de gestão das políticas públicas. Tal ideologia trouxe impactos nas condições de trabalho dos(as) assistentes sociais, em sua maioria trabalhadores(as) assalariados(as) de órgãos da administração pública e, em consequência, sofrendo os efeitos negativos da reforma neoliberal do Estado.

Nas políticas públicas sociais, o governo FHC seguiu o receituário neoliberal de redução das ações sociais do Estado e o estímulo às práticas de "solidariedade social", com transferência de responsabilidades públicas para as organizações não governamentais, além da privatização de um conjunto de serviços sociais públicos que passam a ser intermediados pelo mercado. Substituiu, assim, o princípio da universalização pela focalização em determinados segmentos pauperizados, excluindo-os, cada vez mais, do acesso aos direitos sociais universais.

O desmonte das políticas sociais impactou o trabalho do(a) assistente social na medida em que esse profissional tem atuado diretamente com políticas, programas e serviços sociais nas áreas da Saúde, Educação, Previdência Social, Assistência Social, Habitação, entre outras.

As autoras Alencar e Granemann (2009, p. 168), ao discutirem a ofensiva do capital e as novas determinações do trabalho profissional, destacaram como o desmonte das políticas sociais impactou as condições do trabalho profissional.

Toda essa dinâmica configura uma nova realidade profissional à medida que a tendência de privatização e pauperização da política social face às exigências da contrarreforma do Estado brasileiro são objetivadas no âmbito institucional-organizacional responsáveis pela sua operacionalização e execução. Os impactos para o trabalho profissional são imediatos e fortemente condicionados pelos parâmetros institucionais, dadas as exigências colocadas pelas agências empregadoras e pela realidade do formato do conjunto de programas sociais. Não se pode perder de vista que se trata de diferentes espaços ocupacionais e, certamente, a lógica da pauperização e privatização dos serviços têm expressões diferenciadas na medida em que se trata também de natureza, racionalidades e finalidades institucionais distintas. (Alencar e Granemann, 2009, p. 167) 
Nas organizações públicas, a reestruturação produtiva tem desencadeado novas formas de organização do trabalho, a partir do enxugamento dos postos de trabalho e da ampliação da prestação de serviços através da terceirização da força de trabalho. Além disso, ocorrem perdas de direitos materializados em benefícios, como vale-alimentação, vale-transporte, convênios médicos, entre outros, que deixam de ser repassados aos(às) trabalhadores(as). Por outro lado, mecanismos de aumento da produtividade e alcance de metas foram incorporados, gerando novas formas de controle e fiscalização do trabalho profissional.

No caso do setor público-estatal, a exemplo do setor privado, significativas mudanças tecnológicas levam à incorporação da cultura do gerencialismo, que esvazia conteúdos reflexivos e criativos do trabalho, enquadrando processos e dinâmicas institucionais às metas de controle de qualidade e de produtividade a serem alcançadas. (Raichelis, 2013, p. 624; grifos da autora)

Como parte majoritária dos(as) assistentes sociais trabalha em organizações governamentais, com forte presença da terceirização do trabalho profissional, verifica-se a relevância em discutir o assédio moral nas relações de trabalho do(a) assistente social para identificar de que forma a reestruturação produtiva afetou esses(as) trabalhadores(as) assalariados(as).

\section{Entendendo 0 assédio moral: elementos para sua problematização no trabalho do(a) assistente social}

Fazer uma análise sobre o assédio moral é uma questão complexa, principalmente quando se trata de analisá-lo no contexto das relações de trabalho do(a) assistente social.

Para introduzir o assunto, cabe considerar que a questão do assédio moral ganhou destaque nos anos de 1990, com as publicações da estudiosa francesa Marie-France Hirigoyen (2012), que elaborou o conceito de assédio moral com base nos estudos de Heinz Leymann - pesquisador em psicologia do trabalho na Suécia —, que classificou tal fenômeno de "psicoterror". Segundo a autora:

Por assédio em um local de trabalho temos que entender toda e qualquer conduta abusiva manifestando-se sobretudo por comportamentos, palavras, atos, gestos, 
escritos que possam trazer dano à personalidade, à dignidade ou à integridade física ou psíquica de uma pessoa, pôr em perigo seu emprego ou degradar o ambiente de trabalho. (Hirigoyen, 2012, p. 65)

Figueredo (2012), ao apropriar-se da discussão de Hirigoyen, irá afirmar que o fenômeno do assédio acontece nos âmbitos individual, organizacional e social. Como destaca a autora, a Organização Internacional do Trabalho (OIT) reconhece o assédio moral como forma de violência psíquica, a qual vem ocorrendo em escala mundial. No entanto, é preciso redimensionar a compreensão sobre o assédio moral, extrapolando a concepção da OIT a partir do entendimento de que o fenômeno vem se configurando como estratégia do capital para aprofundar o processo de dominação do trabalho, a partir do acirramento de situações de violência que atingem a alma e o corpo do(a) trabalhador(a), provocando doenças físicas e psíquicas.

Gaulejac (2007), em sua análise sobre o assédio moral na Europa, destaca que:

Três milhões de europeus seriam vítimas de assédio sexual e 12 milhões de assédio ou cerco moral, indica Anna Diamantopoulou em seu relatório ao Parlamento europeu. $\mathrm{O}$ debate sobre o cerco moral pôs às claras a intensidade do mal-estar no mundo do trabalho. O sucesso do livro de Marie-France Hirigoyen (1998) serviu como revelador da importância desse sofrimento social. Particularmente, da ligação entre o sofrimento psíquico, habitualmente confiado a um psiquiatra no segredo de seu consultório, e situações de trabalho vividas no cotidiano. A repercussão de sua obra levará o Parlamento a legiferar. (p. 223-224)

No Brasil, a médica Margarida Barreto introduz o debate sobre assédio moral com a publicação, em 2003, de sua dissertação de mestrado denominada Violência, saúde e trabalho: uma jornada de humilhações.

Para abordar o fenômeno, Barreto (2006, p. 28) elegeu a categoria humilhação "para refletir e compreender seu sentido e significado na relação saúde-doença, bem como sua vinculação com o trabalho e a vida dos sujeitos". Portanto, a autora compreende a humilhação como dor social numa sociedade que é atravessada por relações sociais autoritárias, nas quais predominam o medo e a vergonha, sentimentos que acabam contribuindo para a submissão.

Humilhação é o sentimento de ser ofendido, menosprezado, rebaixado, inferiorizado, submetido, vexado e ultrajado pelo outro. É sentir-se um ninguém, sem valor, inútil; 
magoado, revoltado, perturbado, mortificado, indignado, com raiva. As emoções em nova ordem podem ser causa de liberdade ou servidão. (Barreto, 2006, p. 188)

Segundo Barreto (2006), o assédio moral materializa-se em situações ou atos praticados, com mais frequência, por um superior hierárquico contra um grupo de trabalhadores(as) ou contra um indivíduo em particular, tendo como finalidade forçar a demissão ou o pedido de demissão. De acordo com a autora tais situações associam-se a: falta de clareza nos objetivos do trabalho; instruções imprecisas e confusas, a fim de conduzir o(a) trabalhador(a) assediado(a) a cometer erros; imposição de horários injustificados; atribuição de erros imaginários; críticas públicas de caráter humilhante; solicitação de trabalhos urgentes sem tempo suficiente para a realização; retirada dos instrumentos de trabalho com a finalidade de dificultar a execução da tarefa atribuída; sobrecarrega de tarefas desnecessárias ou não atribuição de atividades devidas; transferência de setor com a finalidade de isolamento.

A gravidade das situações envolvendo o assédio moral fez com que o Conselho Federal de Serviço Social (CFESS) publicasse, em maio de 2011, um manifesto denominado Assédio moral nas relações de trabalho. O conteúdo desse manifesto visou socializar a discussão sobre o assédio moral no trabalho, por entender que ele traz impacto para as relações profissionais e sociais dos sujeitos, além de gerar repercussões negativas à saúde dos(as) assistentes sociais.

Portanto, o CFESS (2011) reconheceu que essa prática danosa vem afetando as relações de trabalho de assistentes sociais. Nesse sentido, é preciso pensar como as formas de gerenciamento das relações humanas no trabalho vêm sendo prejudiciais ao(à) profissional de Serviço Social.

Retomando a discussão de Vincent de Gaulejac (2007), ao discutir o conceito de "ideologia gerencialista", o autor problematiza o mundo gestionário pautado na gestão como ideologia dominante, tratando da banalização do estresse e do assédio moral, entendido por ele como cerco moral.

O sofrimento psíquico e os problemas relacionais são os efeitos dos modos de gerenciamento. A noção de cerco moral tende a focalizar o problema sobre o comportamento das pessoas, mais do que sobre os processos que os geram. Quando o assédio, o estresse, a depressão ou, mais geralmente, o sofrimento psíquico, se desenvolvem, é a própria gestão da empresa que deve ser questionada. Na maioria dos casos, o cerco não é o fato de uma pessoa particular, mas de uma situação de conjunto. (Gaulejac, 2007, p. 225) 
A vítima do assédio é penalizada individualmente pelo sofrimento vivido. Sem a visibilidade sobre o fenômeno que afeta o conjunto dos(as) trabalhadores(as), as situações tornam-se individualizadas, gerando ainda mais sofrimento para o(a) assediado(a), que se sente culpado(a) pelo ocorrido e acaba tendo reforçados os sentimentos de solidão e medo.

Figueredo (2012), ao estudar o assédio moral contra mulheres em uma empresa do setor de plástico voltada para a produção de embalagens, observou que "o assédio moral praticado na empresa estudada não era originário de relações individuais isoladas, a violência era mesmo institucionalizada, gerada, assim como mantida pela gestão em diversas dimensões" (Idem, p. 24-25). Assim, ela constatou que a violência institucionalizou-se como forma de gestão.

$\mathrm{O}$ aspecto da violência no mundo do trabalho apresenta-se como estratégia de dominação do capital sobre o conjunto de trabalhadores(as), desorganizando-os(as) enquanto classe social e despolitizando-os(as) na medida em que ocorre o esvaziamento do potencial reivindicatório dessa classe, ocorrendo a individualização da violência assimilada como culpa do(a) trabalhador(a), e não como forma de violentar os direitos humanos dos(as) trabalhadores(as). Nesse sentido, a solidariedade de classe desaparece para dar lugar à culpabilização individual em relação a questões que afetam o coletivo.

A violência moral é necessária para manter a ordem e a disciplina nas empresas e organizações, como bem enfatizou Barreto (2006). Portanto, ela contribui para reduzir processos coletivos de luta e resistência, enfraquecendo os sindicatos e as entidades representativas dos(as) trabalhadores(as). O desmantelamento dos sindicatos é muito útil ao sistema capitalista de produção, pois desorganiza os(as) trabalhadores(as) e estimula a competitividade e o individualismo exacerbado entre eles(as). Perde-se a solidariedade de classe, deixando o(a) trabalhador(a) totalmente vulnerável aos interesses do capital.

Dessa forma, a violência moral ficará entranhada na subjetividade do(a) trabalhador(a). Portanto, aquele(a) trabalhador(a) que não consegue acompanhar o ritmo de trabalho imposto pelas empresas e organizações, que não atinge as metas estabelecidas, que não apresenta a produtividade requerida, que não corresponde aos objetivos a serem atingidos pelas empresas e organizações, passa a ser considerado(a) "inadaptado(a)", "disfuncional", "preguiçoso(a)", "corpo mole", "vagabundo(a)", "rebelde", "louco(a)". Esse processo de culpabilização do(a) trabalhador(a) fragiliza as relações de trabalho e gera um processo de patologização 
funcional ao capital, pois deposita no(a) trabalhador(a) a "culpa" por ele(a) não se adaptar às normas das empresas e organizações.

A patologização serve para demonstrar aos(às) demais trabalhadores(a)s que tal fenômeno não acontecerá com eles(as), mas aconteceu com o(a) outro(a), porque o(a) outro(a) era um(a) inadaptado(a), um(a) rebelde, um(a) doente. Com grande probabilidade, $o$ (a) trabalhador(a) atingido(a) pela violência moral acaba adoecendo, já que há um comprometimento de sua saúde física e mental, provocando o aparecimento de doenças e/ou fazendo reemergir doenças preexistentes. O(A) trabalhador(a), muitas vezes, não suporta a situação de assédio moral e termina pedindo demissão. No serviço público, acaba ocorrendo a transferência para outro posto de trabalho, além de ameaças de processo administrativo objetivando a demissão do(a) funcionário(a).

A autora Seligmann-Silva (2011, p. 503) analisando a violência no trabalho contemporâneo, destaca o assédio moral como uma das formas de violência psicológica no trabalho.

O assédio moral só se configura quando a dignidade de alguém é atacada de modo repetitivo, sistemático e deliberado durante o período prolongado, geralmente de vários meses. Liderada, explícita ou veladamente, por quem a perpetra, a prática desmoralizante recebe adesões dos demais e se propaga de modo a isolar cada vez mais a pessoa visada. O objetivo é excluir, desqualificar profissionalmente e desestabilizar emocionalmente alguém que, por motivos os mais diversos, tenha se tornado indesejável para o(a) perpetrador(a) do assédio. Glina (2010) verificou uma outra motivação: o interesse de excluir alguém que descobriu uma fraude e que não compactua com esta. Nesse caso, o assédio é perpetrado com o intuito de desprestigiar, desacreditar ou provocar a demissão de quem discorda da quebra ética.

Na sociedade ocidental contemporânea, pensar a ética na sociabilidade erguida sob a égide do capital é uma questão complexa, já que o capital mercantiliza as relações sociais em todas as esferas da vida social. No entanto, é possível pensar numa outra ética que Barroco (2010), com base em Rosa Luxemburgo, denomina de ethos socialista, pautado na exigência da liberdade e da igualdade, da solidariedade, da perseverança, do respeito, da responsabilidade e da capacidade de conservar a sensibilidade, valores presentes no Código de Ética do(a) Assistente Social.

Seligmann-Silva (2011) destaca como aspecto relevante o entendimento de que as condições que induzem à violência podem ser encontradas no trabalho e na 
sociedade, observando que a exacerbação do individualismo e da competitividade contribui para acirrar a violência no trabalho.

A princípio pode ser assinalado que condições indutoras da violência atualmente podem ser encontradas nos dois espaços — trabalho e sociedade —, assim como a inversão de valores éticos e morais: o individualismo, o acirramento da competitividade e o apagamento da confiança e da sensibilidade. (p. 492)

Para a autora, as modalidades de assédio podem ser assim expressas: $o$ assédio do chefe contra o seu subordinado, dos subordinados contra o seu chefe, o assédio horizontal, o individual e o coletivo.

É mais comum que o assédio seja desencadeado por uma pessoa em cargo de chefia e dirigido contra um subordinado competente e dedicado que, justamente por suas qualidades, possa ser percebido pela direção como mais apto a assumir a posição de chefe. Mas o assédio também pode ser desfechado pelos subordinados contra um chefe, pelos mais variados motivos.

Existe ainda a forma horizontal de assédio — na qual os ataques são direcionados a um colega do mesmo nível hierárquico.

Além do assédio individual — voltado a uma única pessoa —, é constatado o assédio coletivo, destinado a atingir um grupo de empregados. (Seligmann-Silva, 2011, p. 503)

Marx, ao analisar a economia capitalista, observa que se trata de uma ciência que abrange $o$ aspecto moral da vida do(a) trabalhador(a).

Por isso, ela [a economia política] é — apesar de seu aspecto mundano e voluptuoso - uma ciência efetivamente moral, a mais moral de todas as ciências. A autorrenúncia, a renúncia à vida, a todas as carências humanas, é a sua tese principal. Quanto menos comeres, beberes, comprares livros, fores ao teatro, ao baile, ao restaurante, pensares, amares, teorizares, cantares, pintares, esgrimires etc., tanto mais tu poupas, tanto maior se tornará o seu tesouro, que nem traças nem o roubo corroem, teu capital. Quanto menos tu fores, quanto menos externares a tua vida, tanto mais tens, tanto maior é a tua vida exteriorizada, tanto mais acumulas de tua essência estranhada. (Marx, 2004, p. 141-142)

Portanto, analisar o assédio moral nas relações de trabalho do(a) assistente social é primordial para entender como esse(a) trabalhador(a) assalariado(a) vem 
lidando com as novas estratégias organizacionais, além de conhecer as formas de resistência e de luta para o enfrentamento dessa questão.

\section{Desvelando o assédio moral no trabalho do(a) assistente social}

A pesquisa desenvolvida por Silva (2014) buscou possibilitar a narrativa das ocorrências de assédio moral nas relações de trabalho de assistentes sociais, bem como o relato da vivência dessas situações pelos sujeitos submetidos às experiências de assédio. Mesmo que o pressuposto que orientou a pesquisa tenha sido a consideração do assédio moral como expressão de práticas coletivas de uma dada organização ou instituição, buscou-se apreender de que forma ele é vivenciado pessoalmente pelos sujeitos e como esses sujeitos reagiram a ele, individual e/ou coletivamente.

Para tanto, a pesquisa foi desenvolvida mediante a aplicação de um questionário individual respondido por assistentes sociais atuantes em diferentes políticas públicas e por profissionais integrantes dos cursos de mestrado e doutorado em Serviço Social da PUC-SP em 2014. Dentre os questionários respondidos foram selecionados cinco que evidenciaram alguns dos critérios definidos por Barreto (2006) e Figueredo (2012) como assédio moral. As identidades desses(as) assistentes sociais foram preservadas, seus nomes são fictícios e outros dados que poderiam identificá-los(as) foram ocultados. O grupo pesquisado atua ou atuou nas políticas sociais de Saúde, Previdência Social, Educação e Assistência Social.

Em seguida apresentamos uma síntese das situações de assédio moral vivenciadas pelos sujeitos entrevistados e identificadas na pesquisa.

Rosa (assistente social, 33 anos). Começou a trabalhar na área da Previdência Social a partir de 2009. Foi aprovada em concurso público e no período em que passou pela situação de assédio moral estava em estágio probatório. Relata que começou a ser assediada com mais intensidade ao fazer um pedido de reconsideração sobre a avaliação semestral do estágio probatório elaborada pela chefia, a qual considerava que ela deveria assumir atividades não pertinentes ao Serviço Social. Em seu depoimento percebeu-se que o assédio foi praticado por ela não concordar com a política institucional e, ao questioná-la, acabou sendo submetida ao assédio moral. A lógica do(a) trabalhador(a) polivalente está inculcada na forma de gestão, fazendo parecer natural que o(a) trabalhador(a), além de suas atribuições e 
competências profissionais, assuma também outras atividades, descaracterizando o trabalho técnico das categorias profissionais. Nesse sentido, a luta de Rosa para manter seu trabalho dentro das prerrogativas técnicas e legais que definem a profissão de Serviço Social acabou encontrando uma organização de trabalho que favoreceu a prática do assédio moral e uma conjuntura que reforçou a omissão e a impunidade do(a) assediador(a). Sozinha em seu sofrimento, ela passou a manifestar doenças físicas e mentais que a enfraqueceram, provocando o seu afastamento do trabalho. Provavelmente Rosa não estava submetida a uma chefia perversa e maldosa, embora não se deva suprimir a responsabilidade individual do(a) agressor(a) e da organização de trabalho, mas estava inserida em uma estrutura institucional que se utilizou do assédio moral como forma de gerir as relações humanas, degradando as condições de trabalho por fazer uso da ordem e da disciplina com base na imposição e no autoritarismo.

Alexandra (assistente social, 50 anos). Ocupa o cargo de assistente social há mais de onze anos em uma prefeitura, na qual já atuou em diferentes espaços ocupacionais. Um dos motivos desencadeantes do assédio foi sua participação em atividades sindicais e também a direção técnico-política impressa em seu trabalho, a qual colidiu com os objetivos organizacionais. Ao não se submeter às imposições da chefia e ao não deixar de atuar nas atividades do sindicato, passou a sofrer uma série de constrangimentos e humilhações que caracterizam o assédio moral. Em seu questionário encontramos o seguinte relato:

Com o trabalho na [política de] Habitação, sofremos outros assédios (era coletivo, umas mais que outras, mas todas). Eu tive um relógio de ponto só pra mim, num lugar distante dezesseis quilômetros do centro, em um conjunto habitacional. Depois na sede da prefeitura, a chefia me mandava para uma sala isolada para fazer relatórios e atividades afins que ela chamava de "quartinho".

Nesse depoimento se apresentam dois tipos de assédio. Primeiro: o assédio coletivo, discutido por Seligmann-Silva (2011), quando é direcionado a um grupo de trabalhadores(as) em que várias pessoas são hostilizadas e humilhadas durante a jornada de trabalho. Segundo: o assédio individual, quando é direcionado a uma única pessoa que passa a ser isolada ou colocada em situação vexatória. Ao relatar que ficava numa sala isolada denominada de "quartinho", Alexandra evidencia o abuso de poder nas relações de trabalho. Nesse mesmo sentido Hirigoyen (2012, p. 128) refere-se às "geladeiras": 
Colocar na "geladeira" corresponde a uma forma de assédio no vazio. A pessoa é rejeitada porque não se adapta mais ao cargo, mas ao mesmo tempo não existe nada de específico contra ela ou porque, devido a um conflito com a hierarquia, torna-se claro que ela não é mais adequada ao espírito da organização [...].

Na situação de Alexandra, ela foi colocada na "geladeira" na medida em que participou das atividades sindicais e não compartilhou dos pressupostos organizacionais, passando a ter uma relação conflituosa com a sua chefia, o que culminou em sua transferência para outro espaço de trabalho. Nesse sentido, é preciso considerar que, para construir estratégias de resistência, o assédio moral necessita ser publicizado, principalmente entre as categorias profissionais que lidam com a constante denegação de direitos, como é o caso do Serviço Social. A discussão coletiva ainda é tímida no que se refere ao assunto. Há necessidade de conhecer com mais profundidade esse fenômeno social a fim de combatê-lo.

Adriana (assistente social, 35 anos). Atua no Serviço Social há aproximadamente onze anos. Em seu posto atual de trabalho encontra-se inserida há cerca de cinco anos, no qual é concursada como docente de Serviço Social. O assédio moral iniciou-se a partir do momento em que o projeto de extensão coordenado por ela passou a ter visibilidade positiva na organização de trabalho. Inicialmente Adriana não é diretamente atacada, já que a chefia passa a direcionar o assédio para uma das integrantes da equipe. $\mathrm{O}$ assédio só irá se direcionar para ela quando passa a defender a colega assediada. Assim, ela descreve:

O assédio se iniciou com a chefia em relação à assistente social por motivos pífios. Pela defesa que eu e outra colega professora fizemos da profissional também passamos a sofrer o assédio moral que se materializava em pedidos que burocratizavam o nosso trabalho e nos colocavam como "destruidoras" do Departamento de Serviço Social da universidade [...].

Apesar de manter um vínculo de trabalho estável como docente, Adriana e sua equipe experimentaram relações hierárquicas autoritárias e burocratizadas, nas quais prevaleceram o desrespeito e a falta de reconhecimento profissional. Nesse sentido, Linhart (apud Seligmann-Silva, 2011, p. 187) denomina a insegurança e a competição no trabalho como "precariedade subjetiva", na qual ocorre o massacre da potencialidade criativa e criadora dos sujeitos, a partir da instauração do medo e da humilhação. 
Aurélia (assistente social, 30 anos). Atua no Serviço Social há mais de seis anos. O depoimento abordou sua atuação em um hospital no qual era contratada como assistente social. Em seu relato informa que o motivo do assédio foi o fato de denunciar à diretoria do hospital a morte de um paciente que aguardou por muito tempo pelo atendimento e acabou falecendo no chão do pronto-socorro. Ao não compactuar com o ocorrido, passa a ser assediada moralmente. Conforme destaca Seligmann-Silva (2011, p. 503), existem situações em que o assédio moral é perpetrado contra alguém que descobriu uma fraude e não compactua com ela. Por razões éticas, Aurélia não compactuou com as condições desumanas nas quais o paciente foi atendido e levado à morte. No entanto, a profissional, apesar de acertadamente ter tomado a decisão de fazer a denúncia, acabou relatando que teve sentimento de culpa por fazê-la quando questionada sobre como se sentiu com o assédio moral e qual foi a sua reação. Em suas palavras: "A primeira reação foi de resistência, mas me sentia bastante fragilizada e, por vezes, culpada".

Assim, a fragilização de Aurélia e o sentimento de culpa a levará ao adoecimento. Sua fala é contundente e expressa o conflito ético em assumir uma denúncia e ser penalizada pelas consequências dela decorrentes, já que uma pessoa, ao ser impedida de exercer sua ética, adoece de fato (Seligmann-Silva, 2011). A situação relatada por ela, além de apontar para a violação dos direitos do usuário, também expressa a violação dos seus direitos enquanto profissional comprometida com a ética no trabalho, na medida em que passa a sofrer o assédio por ter realizado a denúncia. Ela nos coloca diante de uma questão contundente: não foi a denúncia pela violação do direito à vida do usuário falecido que fez com que ela pedisse a demissão, mas a violência perpetrada pelo assédio moral é que a forçou à demissão. A autora Seligmann-Silva (2011), ao discutir a questão do desgaste mental no mundo do trabalho, aborda as formas de violência vivenciadas pelos(as) trabalhadores(as). Assim, para ela, o assédio moral é uma das formas de violência psicológica no trabalho contemporâneo. Nesse sentido, podemos perceber que o assédio moral é algo profundamente danoso para a vida do(a) trabalhador(a), implicando seu adoecimento, além de deteriorar as relações no ambiente de trabalho, podendo levar o profissional à desistência do emprego.

Iracema (assistente social, 46 anos). Trabalha na área do Serviço Social há mais de seis anos; há cinco anos é assistente social da Previdência Social. No questionário respondido por ela, descreve as humilhações sofridas no trabalho: 
Eu era ignorada e [a chefia] nunca se reportava diretamente a mim, sempre mandava recado; situações de humilhação de colocar em xeque qualquer manifestação, cobrando uma confirmação de outra pessoa; obstrução de documento; era preterida quando tinha alguma capacitação; desconto salarial indevido; recusa de atestado médico e indeferimento a todas as solicitações; e tentativa de constrangimento público.

Os fatos relatados dão concretude ao assédio moral. Para enfrentá-lo, Iracema protegeu-se individualmente com documentos protocolados, até que conseguiu a transferência para outro posto de trabalho. Seu relato traduz o sentimento de solidão: "Sentimento de isolamento e pouco apoio das colegas mais próximas. Tentei identificar pessoas aliadas e que poderiam me apoiar, mas não consegui".

O depoimento de Iracema deixa claro que a falta de apoio dos(as) colegas mais próximos(as) amplia os sentimentos de isolamento e solidão. "Dejours (2000, apud Moraes, 2010, p. 208) destaca que o sofrimento do trabalho face às novas exigências se relaciona à solidão, característica da nova organização de trabalho e da cultura do individualismo."

A assistente social também afirmou que não tem encontrado estratégias de resistência com relação às práticas de opressão vividas no trabalho. Apesar de negar as possibilidades de resistência, Iracema se valeu de estratégias defensivas. No entanto, pelos motivos já relatados, a resistência se deu no plano individual, e não no coletivo. Moraes (2010), ao tratar das estratégias defensivas em sua pesquisa, afirma que

foi identificado um grande número de estratégias individuais de defesa, indicando que o individualismo característico das novas formas de organização do trabalho se manifesta também no plano do predomínio das estratégias individuais de defesa, tendo em vista o enfraquecimento do coletivo e das estratégias coletivas de defesa contra o sofrimento. (p. 249)

Contudo, para que a resistência produza efeitos consistentes, os(as) trabalhadores(as) precisam fortalecer-se coletivamente mediante a reflexão sobre o assédio moral no ambiente de trabalho, propondo a participação efetiva dos(as) gestores(as) das organizações e dos(as) trabalhadores(as), incluindo os sindicatos e os conselhos profissionais no debate. Além disso, é preciso ampliar a discussão nas associações da categoria, trazendo-a também para os espaços de formação profissional. 
A análise dos cinco casos de assédio moral vivenciados pelas assistentes sociais em seus locais de trabalho permite algumas conclusões:

- o assédio ocorreu com mulheres na faixa etária entre trinta e cinquenta anos;

- a maioria das profissionais estava inserida no serviço público;

- os espaços sócio-ocupacionais relacionam-se às áreas de Assistência Social, Saúde, Habitação e Previdência Social, nas quais elas trabalhavam como assistentes sociais. Apenas uma relatou a experiência como docente em uma instituição de ensino;

- em um conjunto de dezenove profissionais que responderam ao questionário, cinco vivenciaram o assédio moral, representando $26,3 \%$, o que demonstra um número relativamente alto para um universo pequeno de entrevistados(as).

Alguns aspectos especificam o assédio moral no trabalho das assistentes sociais entrevistadas:

- assédio desencadeado pela defesa das atribuições e competências profissionais;

— assédio provocado por posicionamento político e/ou filiação partidária e/ ou sindical;

- assédio desencadeado pela competência técnica da equipe;

— assédio desencadeado pela defesa de princípios éticos.

Além desses, outros elementos relacionados ao assédio moral podem ser considerados:

- A solidão vivenciada pela pessoa assediada: diante da impossibilidade do diálogo, do compartilhamento e da resolução do conflito por meio da negociação política, aprofunda-se o individualismo, a banalização da injustiça e a apatia diante das situações de violência no trabalho.

- A impunidade e a não responsabilização do(a) agressor(a) e da organização pelo assédio moral: mesmo entendendo que esse fenômeno ocorra em um contexto organizacional que viola os direitos dos(as) trabalhadores(as), não é possível suprimir a responsabilidade individual do(a) agressor(a) e da organização. Embora tenhamos que considerar que o(a) 
assediador(a) esteja também inserido em uma estrutura de trabalho que o(a) pressiona para alcançar os objetivos organizacionais, colocando-o(a) como mediador(a) entre os interesses da organização e os interesses da base dos trabalhadores, a impunidade é um fator que degrada ainda mais as condições de trabalho e gera adoecimento físico e psíquico nos(as) trabalhadores(as).

- As estratégias de resistência: os sindicatos e os conselhos representativos da categoria foram indicados pelas assistentes sociais como um mecanismo coletivo de resistência. No entanto, a atuação política desses órgãos representativos ainda é muito restrita e precisa avançar nas estratégias coletivas de enfrentamento ao assédio moral de assistentes sociais para não reforçar a "judicialização" do processo. Nesse sentido, a ação política deve ser usada como mecanismo de mediação e resolução de conflitos na esfera pública. Judicializar as denúncias de assédio moral não favorece a solução do conflito e acaba por prolongar o sofrimento vivenciado pelo(a) trabalhador(a), considerando que uma possível indenização individual, mediante ressarcimento monetário, não faz desaparecerem a dor e o adoecimento oriundos de situações de assédio moral.

Diante dessas questões, também é preciso problematizar as margens de relativa autonomia do(a) assistente social em seu trabalho, uma vez que as condições concretas para exercê-la, dadas pela precariedade da estrutura organizacional, estão cada vez mais sucateadas, impactando profundamente a política de gestão da força de trabalho e atingindo os direitos do funcionalismo público nas diferentes políticas sociais em que atuam.

Além disso, o adoecimento decorrente do trabalho é um fator que precisa ser mais conhecido pelo Serviço Social, pois são cada vez mais recorrentes os relatos sobre os agravos à saúde dos(as) assistentes sociais, como destaca Raichelis (2013, p. 630):

Os impactos do trabalho na saúde do trabalhador têm sido estudados em vários campos do conhecimento, inclusive pelo Serviço Social, mas ainda muito pouco se conhece sobre o adoecimento de assistentes sociais diante da exposição continuada às mais dramáticas expressões da questão social, lidando com a dura realidade enfrentada por homens e mulheres das classes subalternas na sociedade brasileira; e também 
diante da impotência, em muitos casos, frente à ausência de meios e recursos que possam efetivamente remover as causas estruturais que provocam a pobreza e a desigualdade social. É sabido, contudo, que a intensificação e a elevação da carga de trabalho nos diferentes ramos de atividade e espaços sócio-ocupacionais dos assistentes sociais produzem efeitos sobre o corpo e a mente, podendo resultar, conforme muitos analistas, em um novo padrão de problemas saúde-trabalho decorrentes das novas exigências do trabalho contemporâneo.

Assim, torna-se fundamental discutir quais estratégias individuais e coletivas podem/devem ser acionadas pelos(as) assistentes sociais para expandir as margens de (relativa) autonomia em seu trabalho, em um contexto de intensificação, precarização e violação dos direitos do(a) trabalhador(a), propício à ocorrência de discriminações, violência e assédio moral.

\section{Considerações finais}

O estudo e a pesquisa qualitativa sobre o tema do assédio indicaram que as relações de trabalho do(a) profissional de Serviço Social foram impactadas pela reestruturação do trabalho nas organizações privadas ou públicas, a partir da ideologia gerencialista que impôs novas formas de gestão da força de trabalho assalariada, sendo o assédio moral uma delas. Tal ideologia encontra terreno fértil para se consolidar e expandir num ambiente de insegurança, medo da perda do emprego e aumento da competitividade entre os(as) trabalhadores(as), enfraquecendo a luta coletiva e descartando aqueles(as) que não respondem satisfatoriamente à política de gestão institucional.

Nesse contexto, o(a) trabalhador(a) é submetido a situações vexatórias e humilhantes que se repetem e se prolongam durante a jornada de trabalho, provocando danos morais e doenças físicas e emocionais que fatalmente culminarão no afastamento do trabalho ou na demissão. No serviço público, pode levar a uma transferência do setor de trabalho ou à instauração de um processo administrativo visando à demissão, situação que frequentemente é acompanhada de intenso sofrimento e estresse no ambiente de trabalho e fora dele.

Diante disso, o enfrentamento e as formas de resistência ao assédio moral são mais eficazes quando encontram respaldo na organização coletiva dos(as) profissionais, já que o(a) trabalhador(a) assediado(a) via de regra se encontra em situação 
de extrema vulnerabilidade pessoal, além de não ser tarefa fácil obter provas de assédio moral e comprovar o nexo causal, como nossa pesquisa também evidenciou. Portanto, enfrentá-lo individualmente torna-se uma tarefa penosa para a vítima do assédio moral.

Nesse complexo cenário, as entidades representativas da categoria, as associações profissionais e os sindicatos precisam avançar no debate político sobre um fenômeno que atinge um número cada vez maior de trabalhadores(as), incluindo de maneira crescente os assistentes sociais. No âmbito da formação profissional, a questão do assédio moral também precisa ser amplamente discutida a fim de preparar os novos profissionais para o seu enfrentamento. Para isso, é fundamental a ampliação do debate e da pesquisa que estimule o avanço do conhecimento sobre as situações que desencadeiam o assédio moral entre assistentes sociais nos diferentes espaços sócio-ocupacionais públicos e privados.

No âmbito da política pública de saúde, os Centros de Referência de Saúde do Trabalhador precisam ser convocados mais amplamente ao enfrentamento do assédio moral relacionado ao trabalho e acompanhamento dos(as) trabalhadores(as) vitimizados(as), com espaços e recursos específicos para tal fim.

Com relação à legislação para coibir o assédio moral no ambiente de trabalho, está em tramitação na Câmara dos Deputados o Projeto de Lei n. 7.202/2010, que considera o assédio moral como acidente do trabalho. Portanto, reconhecer legalmente o assédio moral como um fator de risco para a saúde do(a) trabalhador(a) é uma conquista importante nesse âmbito, o que exige intensificar a mobilização coletiva nessa direção.

A conviç̧ão de que a luta contra o assédio moral nas relações de trabalho é uma luta de todos(as) os(as) trabalhadores(as) e demanda, portanto, o estabelecimento de estratégias e alianças políticas dos(as) assistentes sociais no conjunto da classe-que-vive-do-trabalho.

Talvez o mais importante "achado" da pesquisa realizada tenha sido a constatação empírica de que práticas de assédio moral ocorrem também com assistentes sociais, primeiro passo para o seu enfrentamento individual e coletivo.

Recebido em 26/5/2015 - Aprovado em 8/6/2015 


\section{Referências bibliográficas}

ALENCAR, Mônica Maria Torres de; GRANEMANN, Sara. Ofensiva do capital e novas determinações do trabalho profissional. Katálysis [on-line], v.12, n. 2, p. 161-169, 2009. Disponível em: <http://www.scielo.br/scielo.php?script=sci_arttext\&pid=S141449802009000200005>. Acesso em: 30 jun. 2014.

ANTUNES, Ricardo. Adeus ao trabalho? Ensaio sobre as metamorfoses e a centralidade no mundo do trabalho. 14. ed. São Paulo: Cortez, 2010.

. Os sentidos do trabalho: ensaio sobre a afirmação e a negação do trabalho. 2. ed., 10. reimpr. rev. e ampl. São Paulo: Boitempo, 2009. (Mundo do trabalho.)

BARRETO, Margarida Maria Silveira. Assédio moral: a violência sutil — análise epidemiológica e psicossocial no trabalho no Brasil. Tese (Doutorado em Psicologia Social) Pontifícia Universidade Católica de São Paulo, São Paulo, 2005.

. Violência, saúde e trabalho: uma jornada de humilhações. São Paulo: Educ, 2006.

BARROCO, Maria Lucia Silva. Ética: fundamentos sócio-históricos. 3. ed. São Paulo: Cortez, 2010. v. 4. (Biblioteca Básica de Serviço Social).

BEHRING, Elaine Rossetti; BOSCHETTI, Ivanete. Politica social: fundamentos e história. 9. ed. São Paulo: Cortez, 2011. v. 2. (Col. Biblioteca Básica de Serviço Social.)

BRASIL. Plano diretor de reforma do aparelho do Estado. Brasília, 1995.

CFESS MANIFESTA. Assédio moral nas relações de trabalho. Brasília: CFESS, 2011.

DAL ROSSO, Sadi. Mais trabalho! A intensificação do labor na sociedade contemporânea. São Paulo: Boitempo, 2008.

DEJOURS, Christophe. Um suicídio no trabalho é uma mensagem brutal, 2010. Disponível em: <http://www.publico.pt/sociedade/noticia/um-suicidio-no-trabalho-e-uma-mensagem-brutal-1420732>. Acesso em: 16 maio 2013.

DRUCK, Graça. Principais indicadores da precarização social do trabalho no Brasil [versão preliminar]. In: CONGRESSO BRASILEIRO DE SOCIOLOGIA. GRUPO DE TRABALHO SINDICATO, TRABALHO E AÇÕES COLETIVAS, 14., Rio de Janeiro, jul. 2009. Disponível em: <www.coloquio-sso.blogspot.com/2010/04/coloquio.html>. Acesso em: 15 mar. 2012.

FIGUEREDO, Patrícia Maria. Assédio moral contra mulheres nas organizações. São Paulo: Cortez, 2012.

GAULEJAC, Vincent de. Gestão como doença social: ideologia, poder gerencialista e fragmentação social. Tradução de Ivo Storniolo. Aparecida: Ideias Letras, 2007. 
HIRIGOYEN, Marie-France. Assédio moral: a violência perversa do cotidiano. Tradução de Maria Helena Kühner. 14. ed. Rio de Janeiro: Bertrand Brasil, 2012.

MARX, Karl. Manuscritos econômico-filosóficos. São Paulo: Boitempo, 2004.

MORAES, Rosângela Dutra de. Prazer-sofrimento no trabalho com automação: estudo em empresas japonesas no Pólo Industrial de Manaus. Manaus: Editora da Universidade Federal do Amazonas, 2010.

RAICHELIS, Raquel. Proteção social e trabalho do assistente social: tendências e disputas na conjuntura de crise mundial. Serviço Social \& Sociedade [on-line], São Paulo, n. 116, p. 609-635. 2013.

SELIGMANN-SILVA, Edith. Trabalho e desgaste mental: o direito de ser dono de si mesmo. São Paulo: Cortez, 2011.

SILVA, Ociana Donato. Assédio moral nas relações de trabalho do/a assistente social: uma questão emergente. Dissertação (Mestrado em Serviço Social) — Pontifícia Universidade Católica de São Paulo, São Paulo, 2014.

SOUZA, Terezinha Martins dos Santos. Formas de gestão na acumulação flexível: o assédio moral. In: BARRETO, Margarida; NETTO, Nilson Berenchtein; PEREIRA, Lourival Batista (Orgs.). Do assédio moral à morte de si: significados sociais do suicídio no trabalho. 1. ed. São Paulo: Matsunaga, 2011. 